\title{
The Effect of Activities Developed with Web 2.0 Tools Based on the 5E Learning Cycle Model on the Multiplication Achievement of 4th Graders
}

\author{
Mehmet ÖZENÇ* \\ Gaziantep University, Nizip Education Faculty, The Department of Primary Education, \\ Gaziantep, Turkey, ORCID: 0000000163394092
}

Harun DURSUN

Gazi University, Institute of Sciences, The Department of Primary Education, PhD. Student, Ankara, Turkey, ORCID: 0000000323679274

\author{
Selçuk ŞAHIN \\ Ministry of Education, Primary School Teacher, Kayseri, Turkey \\ ORCID: 0000000321921776
}

\begin{tabular}{|c|c|}
\hline Article histo & \multirow{6}{*}{$\begin{array}{l}\text { This study examines the effects of activities developed with WEB } 2.0 \\
\text { tools based on the } 5 \mathrm{E} \text { learning cycle model on the multiplication } \\
\text { achievement of } 4 \text { th graders. Nonequivalent control group pretest-posttest } \\
\text { quasi-experimental design was employed in the study. Two of the three } \\
\text { groups that were equivalent in terms of achievement were assigned as } \\
\text { experimental group and one as control group. While multiplication } \\
\text { activities developed with WEB } 2.0 \text { tools based on } 5 \mathrm{E} \text { learning cycle } \\
\text { model were used in the math classes of the experiment } 1 \text { group, } \\
\text { multiplication activities developed with WEB } 2.0 \text { tools were used in the } \\
\text { math classes of the Experiment } 2 \text { group. The control group math class } \\
\text { was taught according to the } 4 \text { th grade math textbook approved by the } \\
\text { Ministry of National Education. The study lasted } 14 \text { hours (three weeks). } \\
\text { A semi-structured interview form was used to determine student views on } \\
\text { WEB } 2.0 \text { tools. According to the study results, there was no significant } \\
\text { difference between the pretest achievement scores of the experiment } 1 \text {, } \\
\text { experiment } 2 \text { and control group students. A significant difference was } \\
\text { determined between the pretest and posttest scores of experiment } 1 \text {, } \\
\text { experiment } 2 \text { and control group students in favor of the posttest. A } \\
\text { significant difference was found between the posttest achievement scores } \\
\text { between the groups. This difference was in favor of the experiment } 1 \\
\text { group between experiment } 1 \text { and control group and in favor of the } \\
\text { Experiment } 2 \text { group between experiment } 2 \text { and control group. There was } \\
\text { no significant difference between the experiment } 1 \text { and experiment } 2 \\
\text { groups. }\end{array}$} \\
\hline & \\
\hline $\begin{array}{l}\text { Received in revised form: } \\
07.05 .2020\end{array}$ & \\
\hline & \\
\hline & \\
\hline & \\
\hline
\end{tabular}

* Correspondency: mozenc@gantep.edu.tr 


\section{Introduction}

Our ability to understand and apply mathematical concepts, and our calculation and problem-solving skills affect many decisions we make in every aspect of our lives. Since number perception, calculation and problem-solving skills are skills that will benefit every person in their personal, professional and social lives, it is necessary to specialize in this field (Witzel \& Little, 2018). Math is the science of number, space, shape and the relationships between them. The language of mathematics is based on the symbols that all people use (Baykul, 2009). According to Van de Walle et al. (2018), mathematics is a science of pattern and order, which is commonly found in nature as well as in our surroundings encountered on a daily basis. The people who will play an active role in shaping the future in the world we live in will be those who can understand the structure behind all these and do math. In fact, mathematical competence is essential for a good future. Academic and professional pathways are blocked for those who cannot acquire mathematical competence. For this reason, relevant opportunities should be provided and support should be given for all students to learn mathematics (NCTM, 2000).

It is known that many people in Turkey and the world developed negative attitudes towards mathematics because they think that math is a difficult subject and that it is difficult to learn. This starts from elementary school years (Taşdemir, 2009). The main reason why mathematics is a difficult lesson to be learned is that it stays as an abstract subject and is not concretized. In general, abstract concepts are difficult to acquire (Baykul, 2009). This is valid for the four operation skills (addition, subtraction, multiplication, division) that are recognized as the foundation of mathematics. According to Ünal and İpek (2010), one of the subjects that elementary school students indeed have difficulty in is multiplication. Multiplication is an operation that attracts attention from the kindergarten to upper grades, but causes difficulties (Smith, 2016) for learners.

Multiplication is about counting groups of the same size and determining how many elements there are in total. Multiplication is also referred to as repeated addition (Van de Walle et al., 2018). When it comes to children, they follow the developmental sequence below while carrying out multiplication:

- Direct Modeling: children count objects to find the answer.

- Counting Strategies: children perform rhythmic counting to find the answer.

- Derived Information: children try to find the product they do not know by accepting what they know as the beginning point.

- Standard Mathematics Knowledge: Not only can children use multiplication effectively, but they can also express what the verbal problem means (Smith, 2016).

This study was conducted with 90 children (8-12 years). Anghileri (1989) revealed that children rarely use multiplication information, and that older children try to solve questions for which they can find solutions with single multiplication using number patterns. Only 6 out of 90 students solved the questions by using multiplication table information (cited in Smith, 2016). According to this study, elementary school children have difficulties in developing multiplication strategy and doing multiplication. 


\section{E Learning Cycle Model}

In order to realize the objective in the math class, it is necessary to concretize the abstract mathematical expressions and activate more than one sense of the learners. One of the learning approaches that can achieve this is the constructivist approach. Constructivism refers to accessing information and constructing a new structure by bringing the pieces together (Baki, 2008). In constructivist learning, the individual builds new information on his or her prior knowledge. In other words, by linking prior knowledge with new knowledge, it enables a cohesiveness between new knowledge and prior knowledge (Şaşan, 2002). One of the models based on the constructivist approach is the 5E model. This model was developed by Roger Bybee. The concept five Es stands for the first letters of the words Engage, Explore, Explain, Elaborate, and Evaluate, which are the five phases of this model. The following is an overview of the 5 phases of the 5E model (Bybee et al., 2006; Bybee, 2009; Bybee, 2014):

- Engage: In the first phase of the cycle, the teacher fosters student interest and curiosity. At this phase, questions can be asked to activate students' prior knowledge. Students showing surprise and asking questions to get more information such as "how did this happen?" or "I wonder why" indicate student engagement.

- Explore: This is the phase where students are the most active. They realize practical experiences to eliminate misconceptions and clarify their astonishment during the engage phase. At this stage, activities with concrete teaching materials such as generating new ideas and investigating problems using prior knowledge are carried out. Technology-supported teaching materials are not used at this stage.

- Explain: This teacher-led phase gives the teacher the opportunity to explain a concept, process or skill in a more direct manner. At this phase, scientific concepts are presented to students in a clear and understandable way. Using videos, web tools, or software tools can help the teacher explain better.

- Elaborate: Students improve and enrich the concepts they have developed in the previous phases. The aim is to facilitate student learning for them to transfer the information to a new situation. The use of written materials and web-based tools motivate students.

- Evaluate: It aims to evaluate teachers' progress towards achieving learning outcomes. It is the phase where students receive feedback about their (in)efficacies.

\section{WEB 2.0 Tools}

The constructivist approach emphasizes addressing the process of 'constructing knowledge'. The individual must derive knowledge from his or her own activities and discoveries. For this reason, students need to actively pay attention to 'knowledge tools' (Crook et al., 2008). Rapidly developing technology, as it is the case in almost every field, is used in educational spheres. As a matter of fact, transference of technological opportunities to the field of education is a requirement of student-centered approach (Başaran, 2010). According to Turkish Statistical Institute (TÜIK) data, $84,3 \%$ of children between the ages of 6 and 15 use internet for homework or learning, and 79.5\% for playing games. In addition, internet access from home has reached 88.3\% (TÜIK, 2019). With the advances in technology, radical changes have occurred in educational contexts as well. Chalkboards used in our schools have been replaced by smart boards. What is more, instead of getting information directly from teachers, students have become individuals who research, find, share in an interactive environment and are intertwined with technology. According to Carr, Zube, Dickens, Hayter and Barterian (2012), educators are increasingly turning to WEB tools 
to develop, support and deliver educational content. Using technology in education is of great importance for students to internalize knowledge according to multiple intelligences (visualspatial intelligence, intrapersonal intelligence, linguistic-verbal intelligence, and so on) too (Korkmaz, Vergili, Çakır \& Erdoğmuş, 2019). Computer software is used to concretize otherwise abstract Math course (Durmus, 2003; Baki, 1996). The studies conducted suggest that technology-supported mathematics teaching leads to much more positive results than current program-based mathematics teaching (Sönmez \& Artut, 2012; Arslan, 2008).

It is notable that technology becomes meaningful only when used as a fundamental learning tool, not in a computer lab solely once a week. To that end, one of the areas of interest is WEB 2.0 tools, which encourage cooperation, interaction and constructing knowledge (Van de Walle et al., 2018). WEB 2.0 first emerged in 2004 by brainstorming at a web conference organized by O'Reilly and Medialive International and attended by leading companies of WEB world (O'Reilly, 2007). WEB 2.0 refers to a number of new applications and services including an interactive environment and structure. WEB 2.0 tools transform individuals from web readers to web literates. The most important benefit of WEB 2.0 tools to the educational environment is that students and teachers can now exit the classroom environment and become information interactive sharers. Thus, materials created with WEB 2.0 tools will be accessible to everyone using these tools (Horzum, 2010; Elmas \& Geban, 2012; Genç, 2010; Richards, 2010; Eze, 2016). In the past, however, creating web content or a web page was possible by those with high-level knowledge and it required considerable time. It is worth underlining that now with easy-to-use websites, videos, presentations, web pages and web content can be created without knowing any programming (Franklin \& van Harmelen, 2007; Thompson, 2007).

Below, 'The Use of WEB 2.0 Tools' was developed via Mindmeister, one of WEB 2.0 tools.

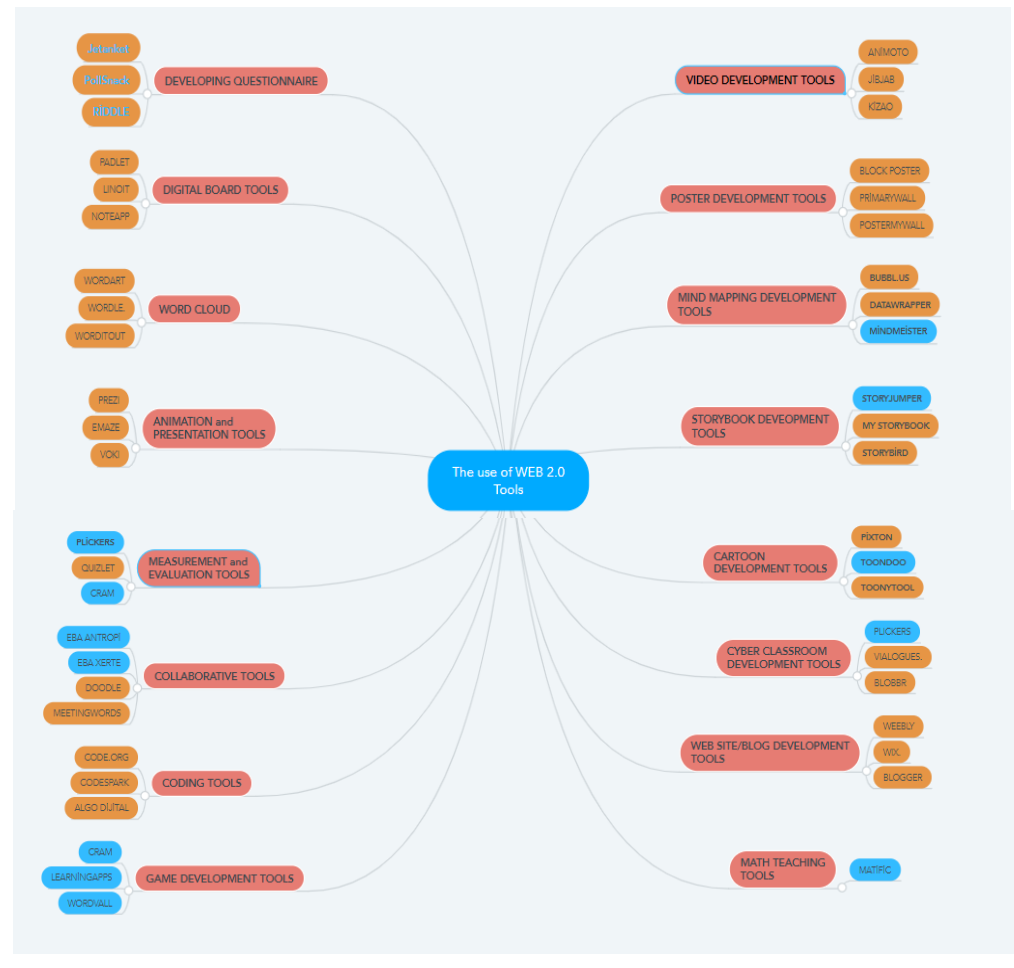

Figure 1. The use of WEB 2.0 tools 
Studies on web-based studies suggest that technology-supported mathematics teaching yields more positive results compared to mathematics teaching using the existing program and also develops a positive attitude towards mathematics (Şengül \& Körükçü, 2012; Sönmez \& Artut, 2012; Topçu, Küçük \& Göktaş, 2014). However, related studies on WEB 2.0 were mainly conducted on teacher candidates and teachers (Franklin \& van Harmelen, 2007; Elmas \& Geban, 2012; Horzum, 2010; Genç, 2010; Tatlı, Akbulut \& Altınışık, 2016; Eze, 2016; Altıok, Yükseltürk \& Üçgül, 2017). There are a few studies conducted at the middle school level (Korkmaz, Vergili, Çakır \& Uğur Erdoğmuş, 2019; Sönmez \& Artut, 2012; Chimo, 2012). In their study examining the usage frequency of WEB 2.0 tools between 2007-2015, Korucu and Gündoğdu (2016) did not find any studies conducted using WEB 2.0 tools at the elementary school level. Similarly, no studies conducted using WEB 2.0 tools at the elementary school level were found in the literature review by the researchers. Based on these studies, it is believed that teaching Math with WEB 2.0 tools according to the 5E learning cycle model, one of the constructivist approaches, will positively contribute to students' multiplication achievement. Thereupon, this study will fill an important gap in the field and will shed light on other studies in the body of literature.

The purpose of this study is to determine the effects of activities developed with WEB 2.0 tools based on the $5 \mathrm{E}$ learning cycle model on the multiplication achievement of 4 th graders. In order to achieve this purpose, answers to the following questions were sought.

(1) Is there a significant difference between experiment 1, experiment 2 and control group students' pretest achievement score means?

(2) Is there a significant difference between experiment 1 group students' pretest and posttest achievement score means?

(3) Is there a significant difference between Experiment 2 group students' pretest and posttest achievement score means?

(4) Is there a significant difference between Control group students' pretest and posttest achievement score means?

(5) Is there a significant difference between experiment 1, experiment 2 and control group students' posttest achievement score means?

(6) What are the views of the experimental group students who were taught mathematics with activities developed with WEB 2.0 tools according to the 5E learning cycle model?

Since no studies conducted examining the effect of activities developed with WEB 2.0 tools based on the $5 \mathrm{E}$ learning cycle model on the multiplication achievement of 4 th graders, the results of this study will be important in terms of the potential contribution to the literature. The study is also significant as to its contribution to teacher training activities carried out in education faculties and particularly to the Basic Mathematics 1 and Basic Mathematics 2 courses offered in elementary school education department. Lastly, this study will also raise teachers' overall awareness about WEB 2.0 tools.

\section{Method}

\section{Study Design}

"Nonequivalent control group pretest-posttest quasi-experimental design" was employed in this study examining the effect of activities developed with WEB 2.0 tools based on the $5 \mathrm{E}$ learning cycle model on the multiplication achievement of $4^{\text {th }}$ graders. The quasi- 
experimental design comes after the true experimental model in terms of scientific value. The quasi-experimental design should be considered and evaluated as "the best possible" design in the current environment. The main feature of this design is that it does not include random assignment (Karasar, 2017; Büyüköztürk, 2016). In this design, there are three groups, namely experiment 1, experiment 2 and control group. No special efforts are made for the random assignment of groups. However, care is taken to ensure that the groups are homogeneous. The decision of which group will be the experiment and which group will be the control group is randomly taken (Karasar, 2017).

The symbolic presentation of the nonequivalent control group pretest-posttest quasiexperimental design to be used in the study is given below.

Table 1: Design symbol

\begin{tabular}{llll}
\hline $\mathrm{G}_{1}$ & $\mathrm{O}_{1.1}$ & $\mathrm{X}$ & $\mathrm{O}_{1.2}$ \\
$\mathrm{G}_{2}$ & $\mathrm{O}_{2.1}$ & $\mathrm{X}$ & $\mathrm{O}_{2.2}$ \\
$\mathrm{G}_{3}$ & $\mathrm{O}_{3.1}$ & & $\mathrm{O}_{3.2}$ \\
\hline
\end{tabular}

\section{G: Group}

$\mathrm{X}$ : Treatment

$\mathrm{O}$ : Measurement, observation

Since this study was carried out with the 4th grade students from three village schools in the same district, equalization of the classes was not possible. For this reason, nonequivalent control group pretest-posttest quasi-experimental design was employed in the study. By selecting similar schools in terms of socio-cultural and socio-economic characteristics, homogeneity was ensured. In addition, a readiness test that tested the $3^{\mathrm{RD}}$ grade multiplication objectives was administered to equalize each classroom's level. This test was developed from the questions in the $3^{\mathrm{RD}}$ grade textbook published by Ministry of Education (MEB) in the 2018-2019 academic year. 10 questions covering five Math objectives were asked. General repetitions and activities were carried out for a week with groups that achieved less than $70 \%$ on the readiness test (Özer, 2000) from the achievements in this test. At the end of a week, the readiness test was administered again. The objectives and table of specifications of the readiness test gain, and the information table of the objectives according to Bloom's taxonomy are presented below:

Table 2. 3rd Grade Objectives and Table of Specifications

$3^{\text {RD }}$ GRADE MULTIPLICATION OBJECTIVE QUESTIONS

\section{TABLE}

M.3.1.4.1. Explains the meaning of times in $1-2$

multiplication.

M.3.1.4.3. Multiplies a two-digit natural number with a maximum two-digit natural number, and multiplies a natural number with a maximum three-digit natural 3-4 number.

M.3.1.4.4. Multiplies with 10 and 100 using a shortcut. 5-6

M.3.1.4.5. Realizes how the product changes when one multiplier is increased or decreased by one using the numbers in the multiplication table up to 5 (including 5).

M.3.1.4.6. Solves problems that require two operations, one of which is multiplication.

9-10 
According to Table 2, two questions were developed for each objective.

Table 3. Information Table of the Objectives According to Bloom's Taxonomy

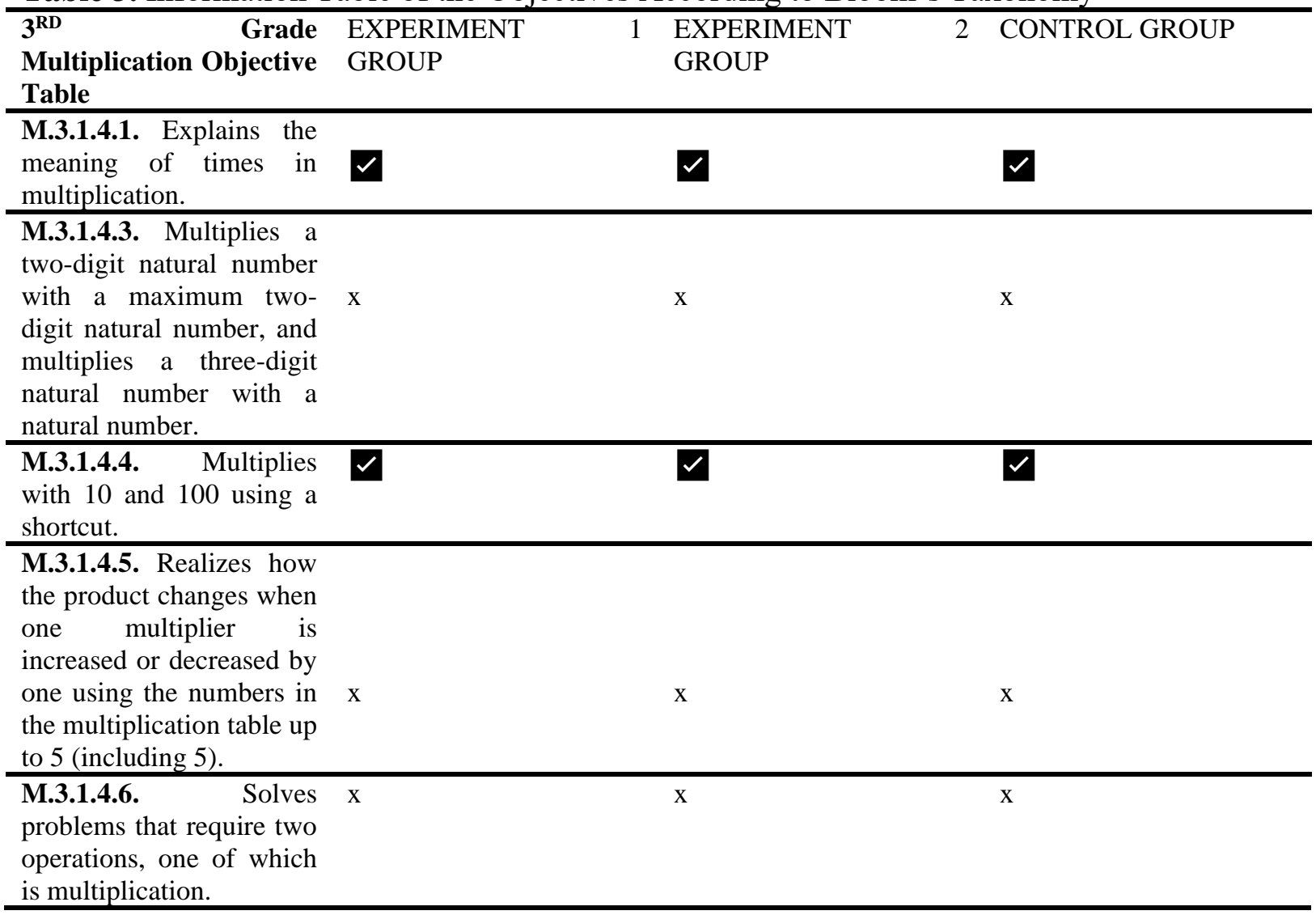

According to Table 3 , the 1 st and 3 rd objectives are fully attained, and $2^{\text {nd }}, 3^{\text {rd }}$ and $5^{\text {th }}$ objectives fell below Bloom's Taxonomy. For this reason, additional lessons were conducted for these objectives.

For each group, subject repetitions and activities for the $2^{\text {nd }}, 4^{\text {th }}$ and $5^{\text {th }}$ objectives were done for a week. By doing this, the researchers aimed to eliminate the difference between students. There was an increase in the posttest scores of the experiment 1, experiment 2 and control groups. Thus, each objective was moved closer to Bloom's taxonomy $(70 \%)$.

\section{Study Group}

The study group consisted of $4^{\text {th }}$ graders attending three different elementary schools in Kayseri during the first semester of the 2019-2020 academic year. For the experiment 1 group, a class at the school where one of the researchers worked was selected, and activities developed with WEB 2.0 tools based on the 5E learning cycle model were carried out with this group. For the Experiment 2 group, the class of a teacher who was knowledgeable about WEB 2.0 tools was preferred, and activities prepared with only WEB 2.0 tools were used with this group. The other group was selected as the control group. The groups had common characteristics such as living in the same region and having similar socio-economic status. In addition, before the experiment, researchers made an effort to equalize students' prior knowledge through the repetition of the subjects for which the necessity to do so appeared according to the readiness test results. There were 16 students in the experiment 1 group, 15 in the Experiment 2 group and 12 in the Control group. 


\section{Data Collection Tools}

In this study, an achievement test was developed by the researchers in order to reveal students' multiplication achievement. The achievement test consisted of a total of 22 questions, two for each learning objective. For content validity, the multiplication achievement test was presented to three instructors and three classroom teachers who were all experts in this field. After receiving expert opinion, a pre-application was conducted with a group of 80 students. Questions with item distinctiveness index r (30) and above were included in the test. The $7^{\text {th }}$ and $11^{\text {th }}$ questions, were excluded from the test because of their low distinctiveness. Croanbach's Alpha reliability coefficient of the final version of the test was found to be 0.84 . In addition, Composite Reliability value was found to be 0.94 . Thus, the final version of the test consisted of 20 questions. In addition, a semi-structured question was asked to determine the students' views on WEB 2.0 tools.

\section{Data Collection}

- Before Treatment: Before starting the study, the experimental and control groups were determined by interviewing the corresponding school administrators and teachers. Readiness test was developed, and students' prior knowledge was determined. Additional classes were taught with a view to reducing the differences between the participant groups. Readiness test was administered again. Then, the activities using WEB 2.0 tools based on the 5E learning cycle model were developed in line with the 4th grade multiplication objectives. The activities developed with WEB 2.0 tools according to the $5 \mathrm{E}$ learning cycle model were given to the experiment 1 group teacher as lesson plans. The activity table and activity examples developed according to the 5E learning cycle model are presented below.

Table 4. Activity Table Developed According to the 5E Learning Cycle Model

\begin{tabular}{|c|c|c|c|c|c|}
\hline Objectives & Engage & Explore & Explain & Elaborate & Evaluate \\
\hline $\begin{array}{l}\text { Multiplies a three- } \\
\text { digit natural } \\
\text { number with two- } \\
\text { digit natural } \\
\text { number. } \\
(3 \mathrm{hr} .)\end{array}$ & $\begin{array}{l}\text { Lattice method } \\
\text { and Japanese } \\
\text { multiplication } \\
\text { method are } \\
\text { presented as a } \\
\text { cartoon using } \\
\text { Toondoo. }\end{array}$ & $\begin{array}{l}\text { Questions about } \\
\text { the cartoon are } \\
\text { asked, and } \\
\text { students learn } \\
\text { how to apply } \\
\text { these methods. }\end{array}$ & $\begin{array}{l}\text { Multiplication } \\
\text { rules (lattice } \\
\text { multiplication } \\
\text { and Japanese } \\
\text { multiplication } \\
\text { method) are } \\
\text { explained to the } \\
\text { students. } \\
\text { Students play } \\
\text { the game of } \\
\text { Wordwall. } \\
\text { Matific } \\
\text { Activities are } \\
\text { carried out. }\end{array}$ & $\begin{array}{l}\text { Problems about } \\
\text { finding the area of } \\
\text { a place or about } \\
\text { shopping are asked } \\
\text { to students by } \\
\text { Toondoo. } \\
\text { Students play the } \\
\text { game developed } \\
\text { by Cram. }\end{array}$ & $\begin{array}{lr}\text { Students } & \text { are } \\
\text { practically evaluated } \\
\text { using a performance } \\
\text { evaluation } & \text { tool } \\
\text { developed } & \text { with } \\
\text { Learningapps. } & \end{array}$ \\
\hline $\begin{array}{l}\text { Shows that a } \\
\text { change between } \\
\text { the multiplier and } \\
\text { multiplicand do } \\
\text { not change the } \\
\text { product in a } \\
\text { multiplication } \\
\text { with three natural } \\
\text { numbers. }(1 \mathrm{hr} \text {.) }\end{array}$ & $\begin{array}{l}\text { How to play the } \\
\text { Circles and Stars } \\
\text { Multiplication } \\
\text { game } \\
\text { explained. } \\
\text { Students draw } 3 \\
\text { stars in } 4 \text { circles } \\
\text { and } 4 \text { stars in } 3 \\
\text { circles. }\end{array}$ & $\begin{array}{l}\text { Students play } \\
\text { the Circles and } \\
\text { Stars } \\
\text { Multiplication } \\
\text { game. }\end{array}$ & $\begin{array}{l}\text { The teacher } \\
\text { gives } \\
\text { explanation. An } \\
\text { activity (finding } \\
\text { the unknown } \\
\text { multiplier) is } \\
\text { done (developed } \\
\text { by Excel). }\end{array}$ & $\begin{array}{l}\text { Everyday } \\
\text { problems are } \\
\text { solved. Students } \\
\text { play the game } \\
\text { Mackpack } \\
\text { developed with } \\
\text { Wordwal. }\end{array}$ & $\begin{array}{l}\text { Students are } \\
\text { evaluated with a } \\
\text { game prepared with } \\
\text { Learningapps. }\end{array}$ \\
\hline
\end{tabular}




\begin{tabular}{|c|c|c|c|c|c|}
\hline $\begin{array}{l}\text { Mentally } \\
\text { multiplies } \\
\text { maximum three- } \\
\text { digit numbers } \\
\text { with natural } \\
\text { numbers } \\
\text { maximum nine } \\
\text { times } 10,100 \text { and } \\
1000 \text { with a } \\
\text { shortcut, and } \\
\text { mentally } \\
\text { multiplies } \\
\text { maximum two- } \\
\text { digit natural } \\
\text { numbers by } 5,25 \\
\text { and } 50 \text { with a } \\
\text { shortcut. (3 hr.) }\end{array}$ & $\begin{array}{l}\text { The 'shortest } \\
\text { cut' cartoon, } \\
\text { developed by } \\
\text { Toondoo, is } \\
\text { shown to the } \\
\text { students. }\end{array}$ & $\begin{array}{l}\text { Students are } \\
\text { tasked to find } \\
\text { the shortest cut. } \\
\text { Then, an activity } \\
\text { (finding the } \\
\text { short cut about } \\
5-10-25-50 \text { and } \\
\text { 100) is done. }\end{array}$ & $\begin{array}{l}\text { The teacher } \\
\text { gives } \\
\text { explanation. } \\
\text { Matific } \\
\text { activities are } \\
\text { carried out. }\end{array}$ & $\begin{array}{l}\text { Everyday } \\
\text { problems on } \\
\text { multiplication with } \\
\text { shortcuts are } \\
\text { presented. }\end{array}$ & $\begin{array}{l}\text { Group evaluation is } \\
\text { done using the game } \\
\text { developed by Cram. }\end{array}$ \\
\hline $\begin{array}{l}\text { Mentally } \\
\text { multiplies } \\
\text { maximum three- } \\
\text { digit natural } \\
\text { numbers by } 10 \text {, } \\
100 \text {, and } 1000 . \\
(2 \mathrm{hr} .)\end{array}$ & $\begin{array}{l}\text { The cartoon } \\
\text { about } \\
\text { multiplication } \\
\text { using a shortcut } \\
\text { and using the } \\
\text { traditional } \\
\text { method, } \\
\text { developed by } \\
\text { Toondoo, is } \\
\text { shared with } \\
\text { students. }\end{array}$ & $\begin{array}{l}\text { Students are } \\
\text { asked the } \\
\text { questions of } \\
\text { "Who do you } \\
\text { think multiplied } \\
\text { faster?" and } \\
\text { "Why?" } \\
\text { An activity (cut } \\
\text { and write below) } \\
\text { is done. }\end{array}$ & $\begin{array}{l}\text { By modelling } \\
\text { the unit cubes, } \\
\text { the teacher } \\
\text { explains that the } \\
\text { number goes up } \\
\text { to } 10 \text { times. The } \\
\text { fun activities in } \\
\text { Matific are } \\
\text { carried out. }\end{array}$ & $\begin{array}{l}\text { Everyday } \\
\text { problems about } \\
\text { multiplying } \\
\text { mentally } \\
\text { presented. are }\end{array}$ & $\begin{array}{l}\text { Evaluation is made } \\
\text { using Plickers. }\end{array}$ \\
\hline $\begin{array}{lr}\text { Estimates } & \text { the } \\
\text { product } & \text { of a } \\
\text { maximum } & \text { two- } \\
\text { digit } & \text { natural } \\
\text { number with a } & \\
\text { one-digit natural } \\
\text { number } & \text { and } \\
\text { compares } & \text { the } \\
\text { estimation } & \text { with } \\
\text { the product. } \\
(2 \mathrm{hr} .)\end{array}$ & $\begin{array}{l}\text { Introduction is } \\
\text { done with Fermi } \\
\text { problems. } \\
\text { Students are } \\
\text { engaged with the } \\
\text { question of 'how } \\
\text { many tea spoons } \\
\text { of sugar can fill } \\
\text { a } 250 \quad \text { mg } \\
\text { container?' }\end{array}$ & $\begin{array}{l}\text { Students are } \\
\text { asked to write } \\
\text { their estimations } \\
\text { on paper. Each } \\
\text { student's } \\
\text { estimations are } \\
\text { hanged on the } \\
\text { board. The } \\
\text { answer that is } \\
\text { most } \\
\text { acknowledged is } \\
\text { hanged on the } \\
\text { classroom board. }\end{array}$ & $\begin{array}{l}\text { The teacher } \\
\text { explains how to } \\
\text { round off to } 10 . \\
\text { An activity } \\
\text { (developed by } \\
\text { Antropi from } \\
\text { the } \\
\text { Project) called } \\
\text { 'Our } \\
\begin{array}{l}\text { Estimations' is } \\
\text { done. }\end{array}\end{array}$ & $\begin{array}{l}\text { Everyday } \\
\text { problems } \\
\text { given. }\end{array}$ & $\begin{array}{ll}\text { Evaluation is } & \text { made } \\
\text { with } & \text { using } \\
\text { Wordwall. } & \end{array}$ \\
\hline $\begin{array}{l}\text { Solves problems } \\
\text { requiring } \\
\text { multiplication } \\
\text { with natural } \\
\text { numbers. } \\
(3 \mathrm{hr} \text {.) }\end{array}$ & $\begin{array}{l}\text { Each student is } \\
\text { distributed } 3 \\
\text { candies. They } \\
\text { are engaged with } \\
\text { the question of } \\
\text { 'How many } \\
\text { candies are } \\
\text { distributed?' }\end{array}$ & $\begin{array}{l}\text { The problems } \\
\text { that were } \\
\text { transformed into } \\
\text { digital stories } \\
\text { using } \\
\text { Storyjumper } \\
\text { and Antropi } \\
\text { from the } \\
\text { question in the } \\
\text { engage phase } \\
\text { and broadened } \\
\text { questions. }\end{array}$ & $\begin{array}{l}\text { The teacher } \\
\text { explains the } \\
\text { problem-solving } \\
\text { steps. } \\
\text { The problems } \\
\text { that were } \\
\text { transformed into } \\
\text { digital stories } \\
\text { using } \\
\text { Storyjumper } \\
\text { and Antropi are } \\
\text { solved. }\end{array}$ & $\begin{array}{l}\text { Everyday } \\
\text { problems are } \\
\text { presented with } \\
\text { EBA xerte. } \\
\text { Feedback to the } \\
\text { questions is given } \\
\text { by EBA xerte. }\end{array}$ & $\begin{array}{l}\begin{array}{l}\text { Students } \\
\text { evaluated by } \\
\text { xerte. }\end{array} \text { EBA } \\
\end{array}$ \\
\hline
\end{tabular}

Thus, WEB 2.0 tools to be used were determined and a three-hour introductory seminar was given to the experimental group teachers for the use of these tools. The purpose of this seminar was to make sure the teachers could use WEB 2.0 tools effectively in their classrooms. The treatment took three weeks (14 hours). The achievement test was administered to the students as a pretest.

- Treatment Process: The treatment took 14 hours (3 weeks). Activities developed with WEB 2.0 tools based on the 5E learning cycle model were carried out with experiment 
1 group students. Only activities developed with WEB 2.0 tools and the existing curriculum were carried out with Experiment 2 group students, and the curriculum available was followed with the control group students.

WEB 2.0 tools used in the application process

Toondoo: It is a free WEB 2.0 tool used to create comics.

Cram: It is a game creation tool. It is also used for evaluation purposes and is free.

Storyjumper: It is a site for creating story books. It is free to use.

LearningApps: It is a fun and free site to create various games.

Wordwall: It is a fun site to create various games. Its use is limited.

Plickers: It is an evaluation tool made with data matrix without using a paper-and-pen.

Matific: It is a site for mathematics teaching and can be used at every grade level.

EBA Xerte: Accessed with EBA*, it is a tool where various activities can be developed.

Anthropy: It is a program that exist in smart boards within the scope of the FATIH project**. Students can prepare presentations, add videos, and use it like the using of paper and pencil by opening multiple pages.

- After Treatment: In the last week of the study, posttest was administered to the experimental and control groups. In addition, the experimental group students filled out the semi-structured interview form developed to determine their views on WEB 2.0 tools.

\section{Data Analysis}

The data obtained from the study were analyzed with the SPSS 21.0 packaged software. For the selection of the analysis technique to be used, it is necessary to test whether the data show normal distribution or not. The skewness coefficient of the pretest used in the study is .291 and the posttest is -.144 . The $\mathrm{Z}$ value of the pretest is 0.806 and 0.398 of the posttest. According to Büyüköztürk (2016), skewness coefficient being in the range of $-1,+1$ indicates that the scores do not deviate excessively from normal distribution. The value of $\mathrm{Z}$, which is obtained by dividing the skewness coefficient by the standard error, being less than 1,96 also indicates that the distribution does not deviate excessively from normal. The skewness coefficient of the pretest and posttest are between -1 and +1 , and the $\mathrm{z}$ values are less than 1,96. Therefore, since the scores had a normal distribution, parametric tests were used. One-way analysis of variance (ANOVA) was performed to determine whether there was a significant difference between experiment 1, experiment 2 and control group pretest scores. Dependent groups t-test was performed to determine to see whether there was a significant difference between the pretest and posttest scores of the experiment 1 , experiment 2 and control groups. One-way analysis of variance (ANOVA) was performed to determine if there was a significant difference between the post-test achievement scores of the experiment 1 , experiment 2 and control group students. Descriptive analysis was employed to determine students' views.

\section{Results}

In this section, statistical analyses for the subproblems are shared, and the findings are presented in tables.

In the first subproblem of the study, the answer to the question of "Is there a significant difference between experiment 1, experiment 2 and control group students' pretest 
achievement score means?" was sought. For this purpose, one-way analysis of variance (ANOVA) was performed to determine the difference between the pretest scores of the groups. The findings are presented in Table 5 and Table 6.

Table 5. Experiment 1, Experiment 2 and Control Group Students' Multiplication Achievement Pretest Arithmetic Mean and Standard Deviation Values

\begin{tabular}{lccc} 
Groups & $\mathrm{n}$ & $\bar{x}$ & $\mathrm{ss}$ \\
\hline Experiment 1 Group & 16 & 10,375 & 34.933 \\
Experiment 2 Group & 15 & 10,600 & 23.524 \\
Control Group & 12 & 9,833 & 21.680 \\
\hline
\end{tabular}

According to Table 5, there is a slight difference between the multiplication pretest achievement score means of the $4^{\text {th }}$ grade students in the experimental and control groups. One-way analysis of variance (ANOVA) was performed to understand whether this difference was significant. ANOVA results are given in Table 6.

Table 6. ANOVA Results Regarding the Multiplication Achievement Pretest Scores of Experiment 1, Experiment 2 and Control Group Students

\begin{tabular}{lccccc}
$\begin{array}{l}\text { Source of } \\
\text { Variance }\end{array}$ & $\begin{array}{c}\text { Sum of } \\
\text { Squares }\end{array}$ & sd & $\begin{array}{c}\text { Mean of } \\
\text { Squares }\end{array}$ & F & p 176 \\
\hline Between Groups & 4,05 & 2 & 2,02 &, 83 \\
Within Groups & 461,01 & 40 & 11,52 & & \\
Total & 465,07 & 42 & & & \\
\hline
\end{tabular}

According to Table 6, there is no significant difference between the multiplication achievement pretest scores of the students in the experimental group and the control group $\left(\mathrm{F}_{(2-40)}=.176, \mathrm{p}>.05\right)$.

In the second, third and fourth subproblems of the study, the answer to the question of "Is there a significant difference between experiment 1, experiment 2 and control group students' pretest and posttest achievement score means?" was sought. For this purpose, dependent groups t-test was employed to compare the pretest and posttest scores within the groups. Analysis results are shown in Table 7.

Table 7. Multiplication Achievement Pretest and Posttest t-Test Results of Experiment 1, Experiment 2 and Control Group Students

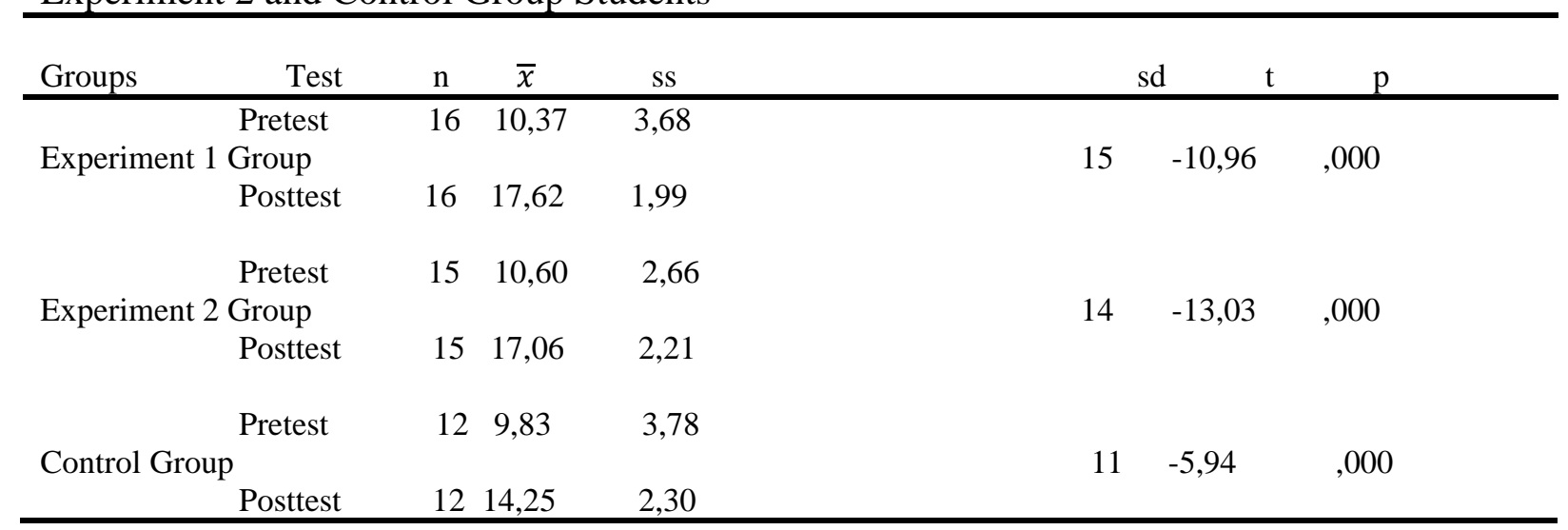


According to Table 7, there is a significant difference between the pretest and posttest scores of the experiment 1 group in which the effect of the activities developed with WEB 2.0 tools based on the 5E learning cycle model on students' multiplication achievement was examined $\left(\mathrm{t}_{(15)}=-10.96, \mathrm{p}<.05\right)$. The difference between the pretest and posttest score means of the experiment 1 group is in favor of the posttest.

In experiment 2 group, the effect of activities prepared with WEB 2.0 tools on multiplication student achievement was investigated. There is a significant difference between the pretest and posttest scores of the experimental group 2 group $\left(t_{(14)}=-13.03, p<.05\right)$. The difference between the pretest and posttest score means of the experiment 2 group is in favor of the posttest.

In the control group, the effects of the activities found in the textbooks prepared by the Ministry of National Education on student achievement were investigated. There is a significant difference between the pretest and posttest score mean of the control group $\left(t_{(11)}=-\right.$ $5.94, \mathrm{p}<.05)$. The difference between the pretest and posttest score means of the control group is in favor of the posttest.

All three groups increased their posttest score means compared to their pretest score means. However, this increase is 7.25 in the experiment 1 group in which activities developed with WEB 2.0 tools based on the 5E learning cycle model were done, 6.44 in the experiment 2 group for whom activities prepared with WEB 2.0 tools were conducted, and 4.42 in the control group where activities developed by the Ministry were done. It can be argued that the learning-teaching activities carried out in the experimental groups were more effective than the activities carried out in the control group.

In the $5^{\text {th }}$ subproblem of the study, the answer to the question of "Is there a significant difference between experiment 1, experiment 2 and control group students' posttest achievement score means?" was sought. For this purpose, one-way analysis of variance (ANOVA) was performed to compare the posttest scores of these groups. The ANOVA results are given in Table 8 .

Table 8. ANOVA Results Regarding the Multiplication Achievement Posttest Scores of the Experiment 1, Experiment 2 and Control Group Students

\begin{tabular}{lcclll}
$\begin{array}{l}\text { Source of } \\
\text { Variance }\end{array}$ & $\begin{array}{c}\text { Sum of } \\
\text { Squares }\end{array}$ & sd & $\begin{array}{c}\text { Mean of } \\
\text { Squares }\end{array}$ & F & p \\
\hline Between Groups & 85,81 & 2 & 42,90 & 9,18 &, 001 \\
Within Groups & 186,93 & 40 & 4,67 & & \\
Total & 272,74 & 42 & & & \\
\hline
\end{tabular}

According to Table 8, there is a significant difference between the posttest scores of the groups. Post-hoc multiple comparison analysis was employed to determine between which groups this difference is. Büyüköztürk (2016: 49) stated that if there is a significant difference as a result of ANOVA analysis, using post-hoc test to identify the source of this difference will strengthen the study. According to the Levene test result, when group variances are homogeneous, Scheffe, Tukey et al. tests and when group variances are heterogeneous, Dunnett C, Games-Howell et al. tests can be employed. According to the study result, group variances were found to be homogeneous with the Levene test $(L(2-40)=9.181, p>.05)$. For 
this reason, Scheffe analysis was used to determine the source of the differentiation between the groups. The Scheffe analysis results are given in Table 9.

Table 9. Scheffe Analysis Results Regarding Multiplication Achievement Posttest Scores of the Experiment1, Experiment2 and Control Group Students

\begin{tabular}{lllll} 
GROUPS & & Mean Difference & Standard Error & P - value \\
\hline Experiment 1 & Experiment 2 &, 55833 &, 77694 &, 774 \\
& Control & $3,37500^{*}$ &, 82555 &, 001 \\
Experiment 2 & Experiment 1 &,- 55833 &, 77694 &, 774 \\
& Control & $2,81667^{*}$ &, 83726 &, 007 \\
\multirow{2}{*}{ Control } & Experiment 1 & $-3,37500^{*}$ &, 82555 &, 001 \\
& Experiment 2 & $-2,81667^{*}$ &, 83726 &, 007 \\
\hline
\end{tabular}

As can be seen in Table 9, the posttest scores of the Experiment 1 and Experiment 2 groups, and the Control group posttest scores differ significantly. The difference is in favor of the experimental groups. No significant difference was found between Experiment 1 and Experiment 2 groups. However, the difference between the arithmetic means revealed that WEB 2.0 tools developed based on the 5E learning cycle model had a higher mean. In conclusion, it can be said that the activities developed with WEB 2.0 tools used in the experimental groups were more effective than the activities used in the control group, and although there was no significant difference between the experimental groups, WEB 2.0 activities based on the 5E learning cycle model were more effective according to the difference between the arithmetic means.

In the $6^{\text {th }}$ subproblem of the study, the views of the experimental group students who were taught mathematics with activities developed with WEB 2.0 tools according to the $5 \mathrm{E}$ learning cycle model were examined. For this purpose, descriptive analysis was employed. Some of the student views on multiplication activities developed with WEB 2.0 tools are presented below.

S1: I liked all of these games. I could not choose between them. It was all very good. I learned the Lattice and the Japanese method. I would like to have more of such games. I played them at home using the internet. ...

S2: I liked every game very much. They were very enjoyable. I wish all our lessons were like this. The games we played improved me a lot. Now, I know how to multiply very well, and I don't get confused at all.

S3: I didn't know how to multiply before. I learned to multiply thanks to these games. The games are all very good. Let's always do it like this....

S4: I liked computer games very much. That was so fun. Thanks to these, my intelligence developed. I do not forget multiplication anymore thanks to games such as story books and horse racing.

S5: I liked the problems developed with stories the most. ... The lattice method is a shortcut to multiply large numbers. I enjoyed not only the problems but all the applications....

S6:... I want the Math course to be taught like this because it is so fun.... 
S7:... The horse racing game was very good. Also, the Lattice and Japanese methods shown in the comics were very fun....

S8: I had a lot of fun. I liked these activities. The activity we did with the data matrix was very good. ... We learned different multiplication methods. The computer game we played as a group was very fun....

S9: The horse racing game, the data matrix evaluation, the painting completion game (matific) and other games were all very good. I love multiplication.

S10: All the activities we did were very good.... I wish we could play again.

According to the findings of the last subproblem, students were satisfied with the study. They stated that WEB 2.0 activities were fun and enjoyable. They also expressed that the activities increased their retention and that they want the lessons to be taught in this way.

\section{Conclusion, Discussion and Recommendations}

In this section, the study results obtained from the findings are given together with the study subproblems. Then, the results were compared with other study results from the literature, and recommendations were offered.

In line with the findings regarding the first subproblem of the study, experiment 1, experiment 2 and control group students were close to each other in terms of multiplication achievement before the treatment. This result is expected and desired because the groups must be close to each other before the treatment. By this way, the effect of the treatment on the groups can be clearly be revealed.

According to the findings regarding the $2^{\text {nd }}, 3^{\text {rd }}$ and $4^{\text {th }}$ subproblems of the study, activities developed based on the 5E learning cycle model, activities developed with only WEB 2.0 tools, and the ones only from the mathematics textbook significantly increase students' multiplication achievement.

In light of the findings regarding the 5th subproblem of the study, the mathematics lesson taught using activities developed with WEB 2.0 tools based on the 5E learning cycle model and activities developed only with WEB 2.0 tools significantly increase students' multiplication achievement compared to the mathematics lesson taught with activities from the textbook. Although the math lessons taught using activities developed with WEB 2.0 tools based on the 5E learning cycle model did not cause a significant difference in students' multiplication achievement compared to the math lessons taught using activities developed only with WEB 2.0 tools, they still increased their achievement.

As for the results obtained for the $2^{\text {nd }}, 3^{\text {rd }}$ and $4^{\text {th }}$ subproblems of the study, they are in line with the other findings from the literature. Ulaş, Sevim and Tan (2012) underpinned that worksheets developed based on the 5E learning cycle model increased student achievement. In their study, Liu, Peng, Wu, and Lin (2009) revealed that learning activities organized on the basis of the 5E learning cycle can improve students' scientific performance, including both their knowledge level and comprehension level. Biyıklı and Yağc1 (2015) put forth that the 5E learning model had a positive effect on students' learning levels. Bilgin, Ay and Coşkun (2013) determined that the 5E learning model was more effective than the traditional learning method during the learning of the subjects of the "let's learn the Matter" unit in $4^{\text {th }}$ grade 
Science course. In the meta-analysis study conducted by Saraç (2017) to examine the effect of the 5E learning model on students' learning products, it was found that the highest effect of the $5 \mathrm{E}$ learning model was on students' retention and academic achievement. Size value in the evaluation of the analyzed studies according to the learning products area was in the permanence and the academic success area of the learned information. Campbell (2006) pinpointed that the $5 \mathrm{E}$ learning cycle model had a positive effect on students' understanding of force and motion concepts. In their study, Dorji, Panjaburee and Srisawasdi (2014) argued that educational computer game applications developed with the 5E learning model constitute an alternative learning and teaching method to traditional education, and provide meaningful learning in subjects of electrical energy consumption and conservation. In his research, Akkaya (2019) determined that the activities developed with WEB 2.0 tools had an impact on students' academic achievement. Gömleksiz and Pullu (2017) reported that the content created with Toondoo, one of the WEB 2.0 tools, positively affects students achievement. In their study, Akçay and Şahin (2012) claimed that Webquest learning, again one of the WEB 2.0 tools, positively impacts students' Turkish Language academic achievement. The results obtained from both this study and other studies show that the 5E learning cycle model and learning activities developed with WEB 2.0 tools positively increase student achievement.

On the basis of the findings regarding the $6^{\text {th }}$ subproblem of the study, the students stated that the activities prepared with WEB 2.0 tools were fun and enjoyable. They also expressed that they want them to be used all the time and they were helpful in retention. This shows that WEB 2.0 tools also develop a positive perspective towards the course. This result is similar to other results encountered in the literature. In their study, Baş and Turhan (2017) reached the conclusion that the Poll Everywhere WEB 2.0 tool they developed increased experimental group students' desire to write and made them want the tool to be used all the time in their writing class. In their study, Kovalik et al. (2014) found out that students responded positively to the lessons done using WEB 2.0 tools. Gömleksiz and Pullu (2017) announce that the activities created with Toondoo, one of the WEB 2.0 tools, positively affected students' attitudes towards the course. In a similar vein, Akçay and Şahin (2012) came up with the result that Webquest learning method, one of the Web 2.0 tools, was effective in increasing students' interest in the Turkish language course. The results of the current study and those of the others in the literature indicate that students love doing the activities developed with WEB 2.0 tools and that they develop positive attitudes towards the course.

We need to equip our children, the architects of our future, with the skills linked to the technology of the 21 st century as children are individuals who get accustomed to using technology, who possess analytical thinking skills, who can work both individually and with a group, who give importance to innovation, and who own strong communication skills along with high self-confidence. Wherefore the transition from information-oriented WEB 1.0 tools to interaction and people-oriented WEB 2.0 tools is considered a necessity in student-centered understanding. WEB 2.0 technology should be used actively in order to create a classroom environment in which the information is not transmitted by the teacher yet constructed by the student. In a classroom with such an atmosphere there are active participant individuals who are technologically literate, they are in the position of producing; not consuming information, and there is product-oriented work. So as to be able to create a new generation of technological tools for use in schools in Turkey, the development of Information Technology classrooms and implementation of the FATIHH Project have been established and it is still continuing. It is believed that these tools should be used starting from the lowest levels of education to assure the infrastructure works meaningfully. For this reason, the introduction of WEB 2.0 tools at elementary school level is of crucial importance with respect to learning and 
increasing sensitivity to technology. Finally, within the scope of results of this study the following recommendations are offered.

- Seminars and in-service activities can be organized to introduce WEB 2.0 tools to teachers, who are the most important factors in bringing these tools into the classroom environment.

- Training sessions on activity development with WEB 2.0 tools can be organized.

- Courses on WEB-based content development can be offered in education faculties, which serves as the pre-professional period.

- In-service trainings can be organized to expand the 5E Model.

- This study was carried out with activities developed with WEB 2.0 tools based on the 5E learning cycle model. Studies can be conducted on the use of WEB 2.0 tools with different learning models.

- This study was conducted at elementary school level. A similar study can be carried out at middle and high school level.

\section{References}

Akkaya, A. (2019). Bilgisayar donanımı konusunda web 2.0 araçlarıyla geliştirilen etkinliklerin ögrenci başarısına etkisi [The effect of the activities developed by web 2.0 tools on computer hardware on student success]. (Unpublished master thesis), Balıkesir University, Institute of Science Computer Education and Instructional Technology, Balıkesir.

Altıok, S., Yükseltürk, E., \& Üçgül, M. (2017). Web 2.0 eğitimine yönelik gerçekleștirilen bilimsel bir etkinliğin değerlendirilmesi: Katılımc1 görüşleri [Evaluation of a scientific meeting about use of web 2.0 technologies in education: The participants views]. Journal of Instructional Technologies \& Teacher Education, 6(1), 1-8.

Arslan, A. (2008). Web destekli öğretimin ve ögrretimsel materyal kullanımının ögrencilerin matematik kaygisina, tutumuna ve başarısina etkisi [The effects of web supported instruction and use of instructional materials on students' mathematics anxieties, attitudes and achievements] (Unpublished Master Thesis). Marmara University, Institute of Educational Science, İstanbul.

Ünal, Z., \& İpek, A. (2010). Gerçekçi matematik eğitiminin ilköğretim 7.sınıf öğrencilerinin tam sayılarla çarpma konusundaki başarılarına etkisi [The effect of realistic mathematics education on 7th grade students' achievements in multiplication of integers]. Education and Science, 34(152). Retrieved from http://egitimvebilim.ted.org.tr/index.php/EB/article/view/8/6

Baki, A. (1996). Matematik öğretiminde bilgisayar her şey midir? [Is computer everything in teaching math?] Hacettepe University Journal of Education Faculty, 12, 135-143.

Baki, A. (2008). Kuramdan uygulamaya matematik eğitimi [Mathematics education from theory to practice]. Ankara: Pegem A Yayıncılik.

Baş, B. \& Turhan, O. (2017). Yabancilara Türkçe öğretiminde yazma becerisine yönelik web 2.0 araçları: Poll everywhere örneği [Web 2.0 tools for writing skills in teaching Turkish as a foreign language: Poll everywhere sample]. Mersin University Journal of the Faculty of Education, 13(3), 1233-1248, DOI: 10.17860/mersinefd.344695.

Başaran, B. (2010). Web tabanl sistemlerde scorm uyumlu whiteboard movie tekniğinin ögrencilerin fizik derslerindeki başarı ve tutumlarına etkisinin araştırılması [The effect of scorm compatible whiteboard movie technique, in web based systems, on students' academic achievement and attitudes in physics courses] (Unpublished doctoral thesis). Dicle University, Institute of Science, Diyarbakır. 
Baykul, Y. (2009). İlköğretimde matematik öğretimi (1-5.Sinıflar)[Mathematics teaching in primary education (1-5. Classes)] (10 ${ }^{\text {th }}$ edition). Ankara: Pegem A Yayınc1lik.

Bıyıklı, C. \& Yağcı, E. (2015). 5E öğrenme modeline göre düzenlenmiş eğitim durumlarının akademik başarı ve tutuma etkisi [The effect of learning experiences designed according to 5e learning model on level of learning and attitude]. Abant Izzet Baysal University Journal of Education Faculty, 15(1), 302-325.

Bilgin, İ., Ay, Y. \& Coşkun, H. (2013). 5E öğrenme modelinin ilköğretim 4. sınıf ögrencilerinin madde konusundaki başarılarına etkisinin ve model hakkında öğrenci görüşlerinin incelenmesi [The effects of 5e model on the 4th grade students' success about substance and their opinions on the model]. Kastamonu Education Journal, 21 (4), 1449-1470.

Büyüköztürk, Ş., Kılıç Çakmak, E., Akgün, Ö. E., Karadeniz, Ş. \& Demirel, F. (2016). Nitel araştırmalar: bilimsel araştırma yöntemleri [Qualitative research: scientific research methods] (11th edition). Ankara: Pegem A. Yayınc1lı.

Bybee, R. W. (2009). The basics 5E instructional model and $21 \mathrm{dt}$ centruy sk1lls. In National Academies Board on Science Education. Washington DC.1-24.

Bybee, R.W. (2014). The BSCS 5E instructional model: Personal reflections and contemporary implications. Guest Editorial,10-13.

Bybee, R.W., Taylor, A.J., Gardner, A., Van Scotteer P., Powell, J.C., Westbrook, A., \& Landes, N. (2006). The BSCS 5E instructional model: Origins, effectiveness, and applications. Colorado: Springs, CO: BSCS

Campbell, M. (2006). The effects of the 5e learning cycle model on students' understanding of force and motion concepts (Unpublished master's theses). University of Central Florida.

Carr, C.T., Zube, P., Dickens, E., Hayter, C. A. \& Barterian, J. A. (2013). Toward a model of sources of influence in online education: cognitive learning and the effects of web 2.0. Communication Education, 62(1), 61-85, DOI: 10.1080/03634523.2012.724535

Chimo, D. M. (2012). Effects of Web 2.0 technology on student learning in science (Unpublished master's theses). Montana State University, Montana.

Crook, C., Cummings, J., Fisher, T., Graber, R., Harrison, C. \& Lewin, C., (2008). Web 2.0 technologies for learning: the current landscap -opportunities, challenges and tensions. A Report Becta.

Dorji, U., Panjaburee, P., \& Srisawasdi, N. (2015). A learning cycle approach to developing educational computer game for improving students' learning and awareness in electric energy consumption and conservation. Journal of Educational Technology \& Society, 18 (1), 91-105.

Elmas, R., \& Geban, Ö. (2012). Web 2.0 tools for 21 st century teachers. International Online Journal of Educational Sciences, 4(1), 243-25

Eze, E. M. (2016). Awareness and use of web 2.0 tools by LIS students at university of Nigeria, Nsukka, Enugu State, Nigeria. Library Philosophy \& Practice.

Franklin, T. \& van Harmelen, M. (2007). Web 2.0 for content for learning and teaching in higher education (Report) http://ie-repository.jisc.ac.uk/148/1/web2-content-learningand- teaching.pdf.

Genç, Z. (2010). Web 2.0 yeniliklerinin eğitimde kullanımı: Bir Facebook eğitim uygulama örneği [Use of web 2.0 advancements in education: A case study of Facebook in education]. Akademik Bilişim'10 - XII. Academic Informatics Conference Papers, Muğla Üniversity.

Gömleksiz, M. N. \& Pullu, E. K. (2017). Toondoo ile dijital hikâyeler oluşturmanın öğrenci başarısına ve tutumlarına etkisi [The effect of digital stories developed by using 
toondoo on students' academic achievement and attitudes]. Turkish Studies, 12 (32), 95-110.

Horzum, M. B. (2010). Öğretmenlerin Web 2.0 araçlarından haberdarlı̆̆ı, kullanım sıklıkları ve amaçlarının çeşitli değişkenler açısından incelenmesi [Investigating teachers' Web 2.0 tools awareness, frequency and purposes of usage in terms of different variables]. International Journal of Human Sciences, 7 (1), 603-634.

Karasar, N. (2005) Bilimsel araştırma yöntemi [Scientific research method](14 ${ }^{\text {th }}$ edition). Ankara: Nobel Yayın Dağıtım.

Korkmaz, Ö., Vergili, M., Çakır, R., \& Erdoğmuş, F. U. (2019). Plickers web 2.0 ölçme ve değerlendirme uygulamasının öğrencilerin sınav kaygıları ve başarıları üzerine etkisi [The impact of plickers web 2.0 assessment and evaluation tool on exam anxiety and academic success of students]. Gazi Journal of Education Sciences, 5(2), 15-37.

Korucu, A. T. \& Gündoğdu, M. M. (2014). Eğitim teknolojilerinde web 2.0 kullanımı 20072015 dönemi makalelerin içerik analizi [The use of web 2.0 technologies in education - A literature review 2007-2015 period]. Journal of Turkish Science Education, 11(1), 3-23.

Kovalik, C., Kuo, C. L., Cummins, M., Dipzinski, E.,Joseph, P. \& Laskey, S. (2014). Implementing web 2.0 tools in the classroom: Four teachers' accounts. TechTrends, 58 (5), 91-95.

Liu, T.-C., Peng, H., Wu, W.-H.,\& Lin, M.-S. (2009). The effects of mobile natural-science learning based on the 5e learning cycle: A case study. Journal of Educational Technology \& Society, 12 (4), 344-358.

National Council of Teachers of Mathematics. (2000). Principles and standards for school mathematics. Reston, VA.

National Council of Teachers of Mathematics (NCTM) (2010). Principles and standards for school mathematics. http://www.nctm.org/Standards-and-Positions/Principles-andStandards/

O'Reilly, T. (2007). What is web 2.0: Design patterns and business models for the next generation of software. Communications \& Strategies, 1(3), 17-37

Richards, R. (2010). Digital citizenship and web 2.0 tools. Journal of Online Learning and Teaching, 6(2), 516-522.

Saraç, H. (2017). 5e öğrenme modelinin öğrencilerin öğrenme ürünlerine etkisi: Metaanaliz çalışması [The effect of 5e learning model usage on students' learning outcomes: metaanalysis study]. The Journal of Limitless Education and Research, 2 (2), 16 - 49.

Sperry, S. S. (2016). Erken çocuklukta matematik [Mathematics in early childhood]. (S. Erdoğan,Trans. Ed.). Ankara.

Şaşan, H. (2002). Yapılandırmacı öğrenme [Constructivist learning]. Yaşadıkça Eğitim, 74(75), 49-52.

Şengül, S. \& Körükcü, E. (2012). Tam sayılar konusunun görsel materyal ile öğretiminin altıncı sınıf öğrencilerinin matematik başarıları ve kalıcılık düzeylerine etkisi [Effect of teaching integers using visual materials on the sixth grade students' mathematics achievement and retention levels]. International Online Journal of Educational Sciences, 4(2).

Taşdemir, C. (2009). İlköğretim ikinci kademe öğrencilerinin matematik dersine karş1 tutumları: Bitlis ili örneği [Elementary education second level students' attitude to the mathematic lesson: an example for bitlis city]. Dicle University Journal of Ziya Gokalp Education Faculty, (12), 89-96. Retrieved from https://dergipark.org.tr/en/pub/zgefd/issue/47955/606751.

Tatlı, Z., İpek-Akbulut, H. \& Altınışık, D. (2016). Öğretmen adaylarının teknolojik pedagojik alan bilgisi özgüvenlerine web 2.0 araçlarının etkisi [The impact of web 2.0 tools on 
pre-service teachers' self confidence levels about TPCK]. Turkish Journal of Computer and Mathematics Education, 7(3), 659-678.

Thompson, J. (2007). Is Education 1.0 ready for web 2.0 students? Innovate 3(4). http://innovateonline.info/pdf/vol3_issue4/Is_Education_1.0_Ready_for_Web_2.0_Su dents_.pdf

Topçu, H., Küçük, S. \& Göktaş, Y. (2014). Sınıf öğretmeni adaylarının ilköğretim matematik öğretiminde eğitsel bilgisayar oyunlarının kullanımına yönelik görüşleri [Views of elementary school pre-service teachers about the use of educational mathematics games in mathematics teaching]. Turkish Journal of Computer and Mathematics Education, 5(2), 119-136.

Tural-Sönmez, M., Artut, P. (2012). Web üzerinden sunulan eğitsel matematik oyunlarının kesirler ve ondalık sayılara ilişkin öğrenci başarısına etkisi [The effect of educational math games offered on the web on student success related to fractions and decimals]. $10^{\text {th }}$ National Science and Mathematics Education Congress, 27-30 June 2012.

TÜİK. (2019). Hanehalkı bilişim teknolojileri kullanım araştırması [Household information technology usage research]. http://www.tuik.gov.tr/PreTablo.do?alt_id=1028

Van de Walle, J. A., Karp, K. S., \& Bay-Williams, J. M. (2013). Illkokul ve ortaokul matematiği: Gelişimsel yaklaşımla ögretim [Elementary and middle school mathematics: Teaching developmentally] ( $7^{\text {th }}$ edition). (S. Durmuş, Trans. Ed.). Ankara: Nobel Akademik Yayıncılık.

Witzel, B. S., \& Little, M. E. (2018). Zorlanan Çocuklar için ilköğretim matematik öğretimi [Elementary mathematics teaching for children who have difficulty]. (M.F. Öçal, T. Kar, Trans. Ed.). Ankara: Eğiten Yayıncılık.

Ulaş, A. H., Sevim, O. \& Tan, E. (2012). The effect of worksheets based upon 5e learning cycle model on student success in teaching of adjectives as grammatical components. Procedia-Social and Behavioral Sciences, 31, 391 - 398. 